\title{
How Do Parents Experience Relocation Disputes in the Family Courts?
}

\author{
Rob George, April Gallwey and Kay Bader \\ (2016) 37 Journal of Social Welfare and Family Law, forthcoming
}

\begin{abstract}
Key words: children, relocation disputes, family justice system, parents' experiences
\end{abstract}

\begin{abstract}
Relocation cases are known to be amongst the most difficult decisions for family court judges. This article reports the findings of an empirical study of parents who were involved in relocation disputes, reporting their views on the experience of being involved in one of these difficult cases. We consider the origins of the disputes and parents' perceptions of how their cases were resolved, as well as some initial discussion of the aftermath of the cases as seen in the first few months.
\end{abstract}

Family court disputes are emotionally, psychologically and often financially difficult for those involved in them, no matter what the nature of the dispute. When the case involves a proposal for one parent to relocate with their child to live in a distant location (whether abroad or not) against the other parent's objection, those tensions are often particularly high.

In this article, we report findings from an empirical study of 34 parents who were interviewed in 2012-13, all of whom had been involved in a relocation dispute which went to court within the previous six months. Our work provides an English sample of parents whose experiences can be compared with that of Australian and New Zealand families who have been the subject of previous research in those countries (Parkinson, Cashmore and Single, 2011; Parkinson and Cashmore, 2013, 2015; Taylor, Gollop and Henaghan, 2010).

This project aims to answer the following research questions:

- What range of views do study participants involved in relocation disputes have about their disputes?

- How have study participants come to be involved in a relocation dispute, and how did they go about attempting to resolve the case?

- What were study participants' experiences of the family justice system, including experience of lawyers, pre-court negotiation, and the court system itself?

\section{RELOCATION LAW}


It is not our intention to say much about the law in relation to relocation disputes, since our focus is on parents' experiences and not the law itself. Nonetheless, a short summary is helpful in contextualising the experiences of our participants.

Put simply, English law differentiates between proposed international relocation disputes, and those proposed moves that are within the United Kingdom, though in both cases the welfare of the child or children concerned is the court's paramount consideration (Children Act 1989, s 1(1)). The welfare principle is then informed by various considerations on the well-known 'welfare checklist' (including, for example, the child's wishes and feelings, the effect of any change in circumstances, and each parent's ability to meet the child's needs). In addition, there is now the so-called 'parental involvement presumption' (Children Act 1989, s 1(2A)), which says that each parent should be involved in the child's upbringing if it is safe to do so though this provision was not in force when the interviews for this research took place.

Beyond that, there is then case law guiding judges in international and internal relocation cases. When the interviews for this research took place, the court was guided by the 2001 Court of Appeal decision in Payne v Payne [2001] EWCA Civ 166, as understood in the light of the 2011 case of $K v K$ (International Relocation: Shared Care Arrangement) [2011] EWCA Civ 793 (also sometimes known as Re K). In Payne, Thorpe LJ set out a 'discipline' of questions to ask when deciding an international relocation case, while Butler-Sloss $\mathrm{P}$ provided 'considerations' to incorporate into the decision-making process. In short, Payne asked about the motivation and level of planning that the applicant parent has, the motivation of the respondent parent, and the effect, both of allowing and of refusing the application.

However, much criticism was made of the way in which these considerations were set out in Payne, especially by Thorpe LJ (Hayes 2006; George 2014, 40-42). The effect of this wording (and subsequent judicial interpretation by the Court of Appeal) was that English law was, for a long time, thought to be 'walking and talking like a presumption' in favour of a relocation application (Geekie 2008). Indeed, when previous research was done with parents involved in relocation cases, a marked criticism that those parents made was that the law was effectively biased in favour of applicant mothers (Freeman 2009).

The 2011 decision in $K v K$ marked something of a sea-change in the approach to international relocation cases. While reiterating the value of the guidance from Payne, Moore-Bick and Black LJJ also stressed that Payne was designed merely to assist judges in reaching their decisions about the welfare of each child, and the questions asked were not intended to involve presumptions or indications of what outcome the court should reach in a particular case. Consequently, while the guidance itself did not change, the courts' approach to using that guidance may have. This is one particularly important justification for the research reported in this project, with interviews all taking place in relation to cases which were resolved after $K v K$.

The guidance has since shifted again following Re F (International Relocation Cases) [2015] EWCA Civ 882, which post-dated the interviews for this research. The effect of $\operatorname{Re} F$ appears 
to be to push Payne further from the centre of the court's decision-making: rather than starting with Payne and then modifying the approach if necessary, the court now seems to be instructed to approach cases in a 'holistic' manner and to use Payne only in cases where it appears helpful. Reliance on Payne without placing it in context is said to amount to an error of law by the judge (see generally Devereux and George 2015). While we discuss this case further in the conclusions, we reiterate that this case reflects a shift in the law as compared with that experienced by our participants.

The guidance in relation to internal relocation disputes, for moves within the United Kingdom, is considerably less developed than its international counterpart. Early cases like Re E (Residence: Imposition of Conditions) [1997] 2 FLR 638 (CA) emphasised that when a parent had been entrusted with the main care of a child, the court would not normally impose conditions about where in the United Kingdom that parent could live. The language used by the courts hardened in the mid-2000s, so that it was said that restrictions on a main carer's place of residence were 'truly exceptional' (Re B (Prohibited Steps Order) [2007] EWCA Civ 1055), but later cases have moved towards a purer welfare approach with less indication about when restrictions may be appropriate (Re L (Internal Relocation: Shared Residence Order) [2009] EWCA Civ 20).

\section{PREVIOUS RESEARCH ON PARENTS' EXPERIENCES OF RELOCATION DISPUTES}

A number of studies have been done previously on parents' experiences of relocation disputes. In England and Wales, a report by Marilyn Freeman (2009) looked at the experiences of parents who were involved with a relocation dispute between 1999 and 2009. She interviewed 25 fathers and 11 mothers, and noted considerable concern amongst participants that, as they saw it, the law prioritised the interests of applicants (almost always mothers) over that of the children, equating the mother's interests with the child's. It was thought, in particular, that the courts prioritised the well-being of the mother above all other factors within an assessment of the child's welfare. Fitting with that perception, Freeman's participants reported that the legal advice that they received was that applications 'will inevitably be granted ... and that fathers should not bother to defend such applications as it is better to try to make good contact arrangements' (2009: 20).

There are a number of aspects of Freeman's research which means that it is timely to conduct a follow-up study. First, her methodology raises a number of concerns, particularly regarding sampling, which have been set out previously (George 2014, 22). More pertinently to this study, the cases discussed by Freeman's participants all pre-dated $K v K$, so the important question arises as to whether that decision has led to a change in perception amongst parents involved in relocation cases.

In other jurisdictions, longitudinal studies have previously been conducted with families involved in relocation disputes. In New Zealand, Nicola Taylor, Megan Gollop and Mark Henaghan (2010) conducted research with 100 families where the mother, the father or both 
were interviewed; in 30 of those families, the researchers also spoke with the children. The study highlighted the huge importance of the relocation decision to all those involved. Where applications to move were allowed, the non-moving parent (almost always the father) reported experiencing uncertainty and distress, and of feeling 'like expendable accessories in their children's lives' (ibid, 95). There applications were refused, on the other hand, applicant parents (mostly mothers) often saw the decision as an infringement of their rights, tying them to their former partners in a way that they saw as highly unfair.

In Australia, Patrick Parkinson, Judy Cashmore and Judi Single (2011) have conducted a similar longitudinal study involving 38 mothers and 40 fathers. Their work has noted how applicants tend to have multiple reasons for seeking to relocate, but that the reasons given by mothers - usually relating to family relationships or new partners - were different from the reasons which the fathers perceived them to have - which more often related to financial issues, jobs or lifestyle improvements. A later article by Parkinson and Cashmore (2013) focused on the experiences of 15 mothers whose applications to relocate ended in them remaining in their existing location, though not all cases involved a final court determination. Looking at these mothers' experiences over five years after the decision was taken, Parkinson and Cashmore found a variety of responses. Some said that they had adjusted to the decision and taken a positive attitude; some were ambivalent, being said to have adjusted to the decision but not accepted it; and a third group had not adjusted at all, continuing to feel trapped and resentful of the decision.

\section{RESEARCH METHODOLOGY}

Participants were recruited to this study based on their having been involved in a relocation dispute within the previous six months. Participants were recruited principally through contacts with family lawyers, but we also publicised our study online, and a number of parents approached us directly. Direct approaches were particularly important where they brought us into contact with parents who had not had lawyers for their case.

Our sample is not, and is not designed to be, representative of the population of families involved in relocation disputes. Our aim was to gain insight into people's experiences, and we sought to get at least five participants in each of four categories: successful applicants, unsuccessful applicants, successful respondents and unsuccessful respondents. Table 1 sets out the sample of participants. In line with most other studies, all our applicants were mothers and all our respondents were fathers (George 2015). While we focused on international relocation cases, six parents approached us who had been involved in internal relocation disputes, and we included them in the study, though their experiences may differ slightly because of the different legal framework applicable to internal relocation cases.

Table 1: number of participants in each core group

Successful applicants (mothers)

\begin{tabular}{|l|l} 
International cases & 5 \\
\hline Domestic (UK) cases & 1
\end{tabular}




\begin{tabular}{|l|l|l|}
\hline \multirow{2}{*}{$\begin{array}{l}\text { Unsuccessful applicants } \\
\text { (mothers) }\end{array}$} & International cases & 6 \\
\cline { 2 - 3 } & Domestic (UK) cases & 1 \\
\hline $\begin{array}{l}\text { Successful respondents } \\
\text { (fathers) }\end{array}$ & International cases & 9 \\
\cline { 2 - 3 } $\begin{array}{l}\text { Unsuccessful respondents } \\
\text { (fathers) }\end{array}$ & Domestic (UK) cases & 0 \\
\cline { 2 - 3 } & International cases & 8 \\
\hline
\end{tabular}

Again, consistent with previous research (George 2015), the vast majority of our international relocation sample involved proposed moves within Europe $(\mathrm{N}=11)$, to North America $(\mathrm{N}=7)$ or to Australasia ( $\mathrm{N}=5)$, with just two international cases proposing to go to other destinations (one to India, one to South Africa). All but three of our applicants were white; parents were typically in their early 40s, while the mean age of their children was just under 7 (which is also in line with earlier studies: George 2015).

Interviews were conducted by Kay Bader and took place between November 2012 and November 2013. Most interviews were done face-to-face, but for the successful applicants in international cases the participants were already in another country, and so interviews were done via skype or telephone. We adopted a semi-structured interview approach, where a number of core themes had been identified in advance, but participants were generally allowed to tell their story as they wished, with the interviewer probing for details and directing to any areas which had not been covered by the parents themselves. We took this approach so as to maximise the extent to which parents were able to tell us their experiences without interference from us, and so as to minimise the extent to which we may have inadvertently biased their accounts in terms of what they felt was important to them. Interviews were transcribed verbatim in preparation for analysis.

Interview analysis adopted a grounded methods approach, though one where many of the core themes of the analysis had been pre-identified by the researchers based on existing knowledge of the issues which were likely to arise. Rob George and April Gallwey analysed all interviews independently, constructing our own coding frameworks, and bringing our analyses together only once each of us was finished. Again, our aim was to minimise researcher bias: coming from different disciplinary backgrounds and having not discussed the interviews in detail before starting coding, we wanted to ensure that the findings of the study reflect the participants' accounts and not our own preconceived ideas.

In writing about the experiences of our participants, we use pseudonyms, and some details of their cases have been changed to ensure that anonymity is protected. While we have 34 participants, there are only 30 distinct cases in our sample, as both parents were interviewed in four cases. Details of those cases have been changed to ensure that each parent is not able to identify what the other has said.

\section{RESEARCH FINDINGS}


In analysing our interviews, a number of core themes arose, and we address them here in the order in which they would usually arise in a relocation case.

\section{How the relocation case arose}

We asked our participants how long it was between the breakdown of the parental relationship and the relocation application. Answers varied from almost no time at all to 10 years, but most of our cases involved a delay of about two years. However, regardless of the length of time involved, it was true that in most of our cases the idea of relocation had been simmering away in the background for quite some time before any formal discussions began. In a number of cases, parents - both mothers and fathers - spoke about how the relocation had been planned while the former relationship was still on-going. Marlies and her partner had moved to the UK together, but "we both agreed that we were going to raise the child in South Africa". Gloria similarly spoke of "an explicit and acknowledged agreement to move back". Several fathers were aware that their former partners had "always been kind of homesick" (Elliot), so for many the application "wasn't unexpected in any way ... Over the course of our marriage, we had talked about relocating to Canada" (Derek). In other cases, the mother was originally from another country, or now had a partner who was, so although there may not have been explicit discussions about relocation, the idea that she might want to move was often not a total surprise to the fathers involved.

Despite the fact that the idea of relocation was often quite well established, the way in which parents approached the issue when they came to the moment of wanting to apply to go varied considerably. Some fathers spoke, with considerable annoyance, about how they found out about the plan to relocate from their children, often weeks before their former partners said anything to them about it:

\section{"The first I heard about [former partner] Gwen wishing to permanently relocate to Spain came from Owen when I picked him up for contact. ... Owen told me about it probably a month before [Gwen did]." (Graham - successful father).}

"I had an inkling that something was happening because [daughter] Polly was chatting away and Australia kept coming up.... [Then one day] I was picking Polly up ... and then Becky, Polly's younger sister, opened the door and said, 'we're moving to Australia!', and then [my former partner] Heather came to the door and said, 'I didn't want you to find out like this', and then handed me half an inch of paper [about the proposed move]." (Ian - successful father).

For many parents, the moment when lawyers became involved was something of a surprise. Eileen, for example, reported that she wrote her former partner an email setting out a tentative idea of moving, which she hoped would form the start of an informal discussion, "and we got back a letter from his solicitors saying, 'absolutely not, under no circumstances'." Frannie had had one or two brief conversations about relocation with her 
former partner, but "we hadn't talked about it for ages, and then all of a sudden I got a letter through the post saying they were going to court. ... I didn't think he'd ever take it that far." For some fathers, like Elliot and Farid, a letter from a solicitor was the first that they knew of the relocation plan at all, but Jakob's experience was possibly the most unusual:

"[We went to court over contact, and] all of a sudden, completely out of the blue, the judge says ... 'so, Mrs C, I presume you would like to move to Sweden at some point'. It came completely out of the blue. And Johanna said yes. 'Well, let me see', he says, 'it's now March - if you want to start at the beginning of a school year, you probably need to file an application pretty soon'. And there was I, sitting with my jaw on the floor, my solicitor the same. ... It hadn't been discussed at this point at all."

Several fathers commented that they thought that their former partners were surprised that they were not able to relocate without consent from the fathers. Conversely, both Laura and Nita reported that their former partners had initially consented to the relocation, only to change their minds later (though in Laura's case she had already moved to Holland on the basis of the original consent, and was required to come back).

\section{Experience of lawyers and judges}

A few of our parents resolved their cases through negotiation, but all of their cases went to court at least once for a preliminary hearing, and most ended with a Final Hearing at which a Judge made the decision about relocation. Almost all our parents had a lawyer for the Final Hearing, though more had experience of doing directions hearings in person. While one or two parents were quite critical of their lawyers, seeing them as being out mainly to make money and as not interested in the children involved, the vast majority of comments about lawyers were very positive. A few, like Jakob, thought that the system of having both solicitors and barristers was "one of the most ridiculous set-ups I've ever been exposed to", but nonetheless described themselves as "very impressed" with the lawyers they had. Nita said that her barrister was "really wonderful", while Elliot thought that his was "amazing very worth his money". Despite losing his case, Joseph found the QC that he hired to be "just phenomenal" and - which seemed important to him - "she was so much better than Carol's barrister, who ... was like a bit of a buffoon" (though her barrister was also a well-known and respected QC). Other parents, like Carina, found the barrister whom their former partner had to be "very nasty and aggressive", usually in contrast to their own lawyer's style.

The cost of lawyers was a serious consideration for many parents. Most of our cases happened before the cut-backs to legal aid in April 2013, and 4 of our mothers and 1 of our fathers had legal aid to pay for their legal fees, with 5 fathers also reporting that their partners had legal aid. (Following implementation of the Legal Aid, Sentencing and Punishment of Offenders Act 2012, relocation disputes are no longer eligible for legal aid funding unless the parent has established him/herself to be the victim of domestic violence.) Two fathers hired barristers without going through solicitors, under the "direct access" scheme. Their fees of 
$£ 2,000$ and $£ 5,000$ were much lower than those who used solicitors as well, though it is fair to say that their cases were relatively straightforward compared to many, and they also had to do a lot more preparatory work themselves since there was no solicitor to help them.

Moreover, Graham, whose barrister cost $£ 5,000$, thought that the barrister "got quite involved with it on a personal level and ... she gave me a lot of help without charging me, I think", while Derek’s $£ 2,000$ bill did not include a Final Hearing because the case settled before trial.

At the other end of the spectrum, Elspeth's final bill (including her divorce as well as the relocation application, which she lost) “was something like £212,000, and Howard's was $£ 390,000$ ". Leaving these extreme cases aside, the average cost of legal fees for applicants in this study was $£ 34,000$, and for respondents was $£ 37,500$. For many parents, this cost had left them, in Elliot's words, "hugely in debt"; Ian and Phil had both re-mortgaged their houses to pay for their cases, while Emily (who was allowed to relocate away from a father whom she found controlling and threatening) said of her case, "for my freedom, I am now bankrupt - I don't own anything".

Views about the judges themselves were mixed. On one side, despite having lost his case, Alan spoke for several parents when he said, "I think this judge was really fair. He spoke very fairly to me, as he did to my wife." Elliot, who won his case, was impressed with the judge's manner:

"The judge was very amenable, like a very polite headmistress. Very firm, but you could sense she had a genuine feeling for the children - kept coming back to the children as the focus."

Others had a very different impression, as Allie explained:

"The judge was hell-bent on finding against me. It really felt like the process was one-sided, like the judge had made up his mind [before the case had started]."

Similarly, Elspeth described her judge as being "very sweet" during the hearing, but felt that, in the end, the decision had been taken before things started:

"The judge could have saved us all a load of time and a load of money if she'd just sat down and said, 'something I need to tell you - I'm not ever going to give you leave to remove.',

Of course, it is doubtful that the judge would have agreed with that assessment, and judges who have been interviewed for previous research have spoken about how difficult relocation cases are and how much care and attention they need (George 2014).

Many parents thought that a lot depended on the individual judge that they had had for their case. Graham won his case "so I can't complain too much", but still thought that "you do feel sometimes that if you had a different judge on a different day, it would have meant a different 
decision". For some parents, this view was reinforced by conversations with their lawyers:

"We show up at court [for the Final Hearing] and they'd changed the judge... and [my lawyers] just said, 'we've lost - there's no way with this judge that we have a chance'. ... I was shocked." (Gabriel - unsuccessful father)

"[My solicitor] told me right from the start, 'it's very pot luck - it basically depends on the judge's mood on the day', which I found was true. ... The judge walked in and said, 'the mother seems to think she can do whatever she wantswe're going to sort that', and I thought, 'but we haven't even spoken yet - she doesn't even know what's happened'. ... So we kind of felt, well, she's made up her mind." (Carina - unsuccessful mother).

A few parents had specific things that had made them unhappy with their judges. Robert's case was particularly striking:

"After a day and a half in court, the judge hadn't even got [my daughter] Elsie's name right. And he kept on - every time, he said the wrong name. Unbelievable."

These experiences suggest that parents place high value on the appearance of judicial impartiality and knowledge of the details of the case. While judges may see it as helpful to give a preliminary indication of how they see the case at the start, since it helps lawyers in particular to focus their attentions on the areas where the judge has questions, for parents these remarks can be interpreted as the judge having pre-determined the matter.

\section{Experience of the court hearing}

Whether they won or lost, parents generally found the court hearing to be "horrible ... emotionally distressing" (Eileen), describing it as "hard-going" (Allie), "probably one of the worst days of my life" (Malcolm) and as a "distressing nightmare" (Christian). For many parents, the focus of these remarks was on the experience of giving oral evidence and being cross-examined.

One mother, whose application was refused, felt that she had had no control over the case at all:

"Cross-examination - that was just a horrible thing! ... The way you get painted is shocking and I just felt ... that I didn't get a chance to tell my story to the judge.... I got in trouble from the judge, because she's like, 'this is not about you getting your points across, Ms Smith', and I'm like, 'but when do I get to put my points across?"' (Gloria - unsuccessful mother). 
As the quotation from Gloria illustrates, because the focus of the time in court was spent being asked difficult questions by the other parent's lawyer in cross-examination, parents often felt that they never had chance to tell their story in the way that they wanted. Parents in our study struggled to understand the court process, whereby the statement that they had written in advance of the hearing was used as their primary evidence, and felt disempowered by this process.

Other parents were also unhappy with their evidence, but for different reasons. Joseph was able to talk with wry amusement about why things had not gone as he'd hoped:

"[I've done] training as an expert witness, and my barrister said, 'short and sweet', and a lot of the training is about not talking too much so you don't give [the barrister asking questions] too much to grab onto.... And I finished [my evidence] thinking to myself, 'I nailed that, I was great', and my barrister goes, 'Joseph! What happened to short and sweet?!'.' (Joseph - unsuccessful father).

Several parents talked about the difficulty of trying to walk the line between saying things to help their own cases, and trying not to be negative about the other parent. In a very emotional part of her interview when she struggled to get words out through her tears, Elspeth explained the challenge:
"I didn't lose it, but God it was stressful. It's so hard because you just want to break down and cry ... and in amongst all that emotion of what you're talking about, all you can think about is, 'I've got to try and make sure I don't refer to the children as "my" children, it's got to be "our" children, and I've got to make sure I'm always talking about Howard in a positive light', even though you really want to say he's a fucking wanker. It's horrendous." (Elspeth - unsuccessful mother).

Both mothers and fathers thought that their former partners were "playing to the judge", as Marlies put it. She felt that her former partner "was trying to make the judge feel sorry for him. You'd be heartless if you didn't - I felt sorry for him!' Several fathers were particularly sceptical about whether, when their former partners cried in the witness box, that was real or not:

"In the 19, 20 years that I've been married, I've never seen her cry once. Was that a bit of tactics going on there? I'll give her the benefit of the doubt." (Simon - successful father.)

"So Hannah stood up in the witness box ... and she did a bit of crying - but the one thing absent from the crying was tears." (Robert - unsuccessful father.)

A common theme was that parents who had previously had quite amicable relationships with their former partners now found that things were being said that they found "quite offensive" 
(Malcolm). Elspeth and Leon had similar experiences of watching their former partners giving evidence:

"Howard came across so badly. He couldn't say anything good about me. [My barrister] would say, 'but you would say that Mrs Crosby is a good mother, wouldn't you?', [and Howard would reply], 'no, she's no better than any other'." (Elspeth - unsuccessful mother).

"[My barrister] asked the question, 'do you think Leon is a good father?'. Her answer was, 'it depends on your definition of a good father', which is absolutely ridiculous. It doesn't cost anything to say, 'he's a good father', if you're clever." (Leon - successful father).

Several fathers who succeeded in opposing the relocation application commented that they thought that the outcome was more down to their former partners than to them:

"I didn't win this case. She lost the case, which is very different." (Leonsuccessful father).

"The decision went in our favour. Some of that was down to what we did, but most of it wasn't. Most of it was down to a decision on Alyssa's behaviour and the case she put." (Elliot - successful father).

\section{Gender differences}

As noted earlier, one the main criticisms of English relocation law following Payne v Payne was that it was effectively biased in favour of mothers, and this was one of the key concerns expressed by parents in earlier research (Freeman 2009). It is generally thought amongst lawyers that the 2011 decision in $K v K$ has shifted that approach, in particular reducing the focus on the applicant parent's well-being as part of the welfare equation. Given this perception by lawyers, we were keen to know how our participants saw the process, given that all their cases were resolved after $K v K$. Mothers and fathers saw these issues quite differently, and so we divide our analysis accordingly.

Fathers' perspectives

Amongst the fathers interviewed, the majority were emphatic about the courts being 'bias' towards the mother. While research has consistently concluded that there is no systemic bias in the family justice system (see, eg, Hunt and MacLeod 2008; Harding and Newnham 2015), men in our study strongly expressed the view that fathers enter into relocation disputes on an unequal footing, many suggesting that the outcome was pre-determined because of an inherent privileging of the mother: 
"We men know what happens in these cases [...] They [the courts] rubber-stamp cases based on the gender of the parents." (Steve - unsuccessful father).

"I think the weight of the law is very much weighted in favour of the mother still." (John - successful father)

"I don't think the system is geared in the direction of men and women equally." (Samuel - unsuccessful father)

The view that the legal system is unjust towards fathers was expressed not only in relation to the courts, the judges and legal representatives, but also the court's child welfare advisory service, Cafcass, although this complaint was made less often:

"I think there's a massive abuse of power of the mother in terms of the professional services, Cafcass ... It's like the mother says ' $x$ ' and it's [treated as being] true." (John - successful father).

Fathers who considered themselves victims of an unfair system for this reason were not only those who had lost their cases, but also those who had won, as this successful father states:

"You start as a father in a worse position than the mother, so it's much harder to believe you have a chance to win...I still believe there is a lot of bias towards the primary carer." (Malcolm - successful father).

Some fathers gathered internet evidence, quoted statistics and referred to public reports about father's rights in the courts (for example, the 'Relocation Campaign' (www.relocationcampaign.co.uk), led by Michael Robinson) to substantiate their individual complaints of unfair treatment:

"I thought, well, I've read enough of the cases, I've read the statistics, I know what the odds in my favour are - or not as the case may be - so I guess as a father I'm starting on the back foot here, we'll see how it goes." (Malcolm - successful father).

By far the most common reference to a generalized sense of injustice was in fathers' frequent mention of Payne v Payne as the origin of the legal system's preferential treatment of mothers in the relocation context: "It was this thing about Payne v Payne" (John - successful father). For many fathers who talked about Payne, the concern was the centrality of the mother's mental health and stability, with a perception at least that it was judged to be in the best of interests of children that a mother not be refused relocation if her mental health was seen to be in question. This aspect of the case was commented on by some of the fathers as establishing preferential treatment of mothers, above all members of the family:

"So much of the relocation thing is about what's best for mum, not what's best for the kids" (John - successful father). 
"And the thing is there is a lot of emphasis on the stress of the mother - the Payne case" (Leon - successful father).

As we discuss in the conclusions to this article, it is interesting to wonder whether the more recent Court of Appeal decision in Re F (International Relocation Cases) [2015] EWCA Civ 882 may have affected this issue. However, it is interesting to note that some fathers saw the apparent influence of Payne as simply reinforcing the sense that they had of a system which disadvantaged them from the outset because of a broader gender bias. In one interview, a father recalled how a judge had actually drawn attention to the fact that all the professionals in his case were female, suggesting that it would be justifiable if he felt undermined:

"And the judge actually made a reference to that and said, 'I hope you don't feel uncomfortable being the only man in the room.' Maybe it's a sign of the time but an interesting role reversal. I'm not intimidated in that kind of situation, but I just thought it was interesting. I was thinking am I going to get an unfair hearing because I'm the only man in the room, or the father in this case?" (Simon - successful father)

In the face of these interviewees' belief in the injustice underlying the family courts' treatment of fathers, it was perhaps not surprising that many of them used the language of 'battle' to describe their experiences:

"Basically she decided to go on a war on me for that...It's really been like a full-out war." (Christian - unsuccessful father)

"I'm pretty sure that the fact the mum was not on top of her game gave me a chance. ... You need to go step-by-step, fight every battle, win every battle... So that's why you need to think about battles, to win battle after battle." (Leon - successful father)

"Don't give up. Keep fighting." (John - successful father)

Although the language of conflict is prominent in the language of the legal process and advocacy generally - we speak of 'winning' cases, and 'legal battles' - it was the male interviewees' who used this language to describe their experiences, much more so than the female interviewees. Although fathers could refer to the personal nature of the battle between themselves and their ex-partner, it was more often the case that this language was employed to describe a conflict between the father and a system which he perceived as set against him:

"I think in general I went into this pretty unhappy, with the perception that as the dad, I was fighting an uphill battle." (Derek - successful father)

It is interesting to note that, for many fathers at least, the difficulties with Payne remained valid even after the re-appraisal in $K v K$. Again, the effect of $\operatorname{Re} F$ remains to be fully assessed, but it may be that this can be seen as a further reason to support wholesale change 
in the legal guidance, as called for by some (Devereux and George 2014): if fathers perceive Payne as importing a bias, that may be as much a problem for the law as if it actually involved bias, since it affects the extent to which justice is seen to be done.

\section{Mothers' perspectives}

In direct contrast to the view expressed by fathers that the courts were bias towards the mother, the majority of female interviewees held the opposite view, that the father was in a privileged position and that instead of an absence of paternal rights, it was the rights of the father which held centre stage:

"I think the judge would have loved to have found in favour of the father. That's the impression I got." (Eileen - successful mother)

"There is definitely a push to provide whatever the father wants really." (Cecile successful mother)

"Yeah, I heard they're completely just going one way and it's all going to the father." (Marina - unsuccessful mother)

Such observations came from women who had been both successful and unsuccessful in the outcome of their cases. A few of the interviewees made a point of claiming that the courts were responding to the demands of social movements for fathers' rights in the courts, such as Fathers for Justice, established in 2001 and whose most recent campaign claims that 'Having a father is a human right' (see www.fathers-4-justice.org). One interviewee claimed: "they're so scared of these dad's rights movements that that they don't dare do anything" (Carina unsuccessful mother). Another mother recalled how her solicitor advised her that she was going to court at a time when the prominence of the fathers' rights movement was having a marked impact on the outcome of cases like her own:

"So she said, well, you never know because there's a whole movement right now for dads and that is really impacting on what is right for the children." (Cecile successful mother)

In two cases involving fathers who were violent and abusive, the mothers describe having their requests to relocate denied and contact between their children and the father actually reinforced by the courts. The violence and abuse of these men seems to have be circumvented or minimized and contact with the father seen as an end in itself, regardless of their historic and ongoing record of violence, known to the courts. In one case a mother recalled how she had been repeatedly raped by the father of her child and claimed he also abused their son. Social services, the police and domestic violence workers were heavily involved and the father had a non-molestation order out against him as a consequence of stalking the mother (Marina - unsuccessful mother). The courts not only declined her request to remove the child from the UK and relocate to her home country, Greece, but agreed that the father should have 
significant overnight contact every week. The mother's response to this outcome was to feel that "they've [put] our abuser right back in control" (Marina - unsuccessful mother).

Another mother whose ex-partner was ordered to have supervised contact with his child as a result of his substance dependency and violence, after being unsuccessful in her request to relocate, described the impact of the court's decision to sustain regular contact between the father and child and her reluctance as a result of feeling unheard and fearful of the father's response to re-enter into a further legal challenge:

"We've just lived for Eve seeing her dad. And the reason I did was because the alternative wasn't worth contemplating. It was dealing with a really aggressive man who would come and thump on my door. It was having to go back to court. And do you know what I thought, I'll just give in." (Emily - successful mother)

These examples as told by our participants suggest that the courts will often go to great lengths to prioritise contact with fathers, which runs counter to the suggestion that the courts neglect paternal rights. Although we are looking only at a small non-representative sample here, we see echoes of earlier work addressing concerns at the courts down-playing incidents of violence in the name of contact (see, eg, Rhoades 2002; Kaganas 2006 and 2013; Smart 2006). In both the interviews quoted above, what stands out is the very limited attention apparently given to the vulnerability of the mother (and child) in the face of a violent expartner, and more widely a perceived negation of the mother's viewpoint and knowledge. A language of 'rights' in relation to motherhood was not used by any of the female interviewees about their own situations, which marks an interesting contrast to the findings of the New Zealand study, where mothers who were prevented from relocating constructed this as being an infringement of their rights (Taylor, Gollop and Hanaghan 2010, p 95). Conversely, the mothers in our study noted the currency of the language of fathers' rights as giving an automatic platform to fathers:

"I just feel like we've gone a little bit further on this fathers' rights thing by saying, if there's a guy who sits there and promises a bunch of stuff, we believe him." (Gloriaunsuccessful mother)

"Everybody kept going on about father's rights - I felt that as the mother everyone was against me." (Marlies - successful mother)

A complaint amongst the female interviewees was that their specific experience and standpoint as a mother was not taken into account or valued during the legal process:

"And it was like all the stuff that I spend 80\% of my life doing, which is being a mum, just counted in about 5 sentences max in the whole thing, which is taken as air." (Gloria - unsuccessful mother) 
The accusation from fathers that mother's were given a privileged position in the courts was strongly challenged by many female interviewees, who instead felt that their experience being the 'primary carer' of their children was overlooked in terms of its significance and insight into their children's needs:

"I didn't get to talk about my kids. I mean, of all the people in that room, I know those kids, and my ex partner, yes, they're his kids too, but the hours and days and years of my life that I've spent for those kids, with those kids, doing everything for them."

(Gloria - unsuccessful mother)

Female interviewees placed a strong emphasis on being mothers, such as one interviewee referring to this aspect of her life as her job: "My primary job is to be their mum" (Elspeth unsuccessful mother). In light of the female interviewees' descriptions of the importance of their work as mothers (rather than as parents), the gender-neutral terminology of 'primary carer' can be argued to obscure the specifics of mothering and the significance attached to mothering as a distinct parental role. Despite the importance that they placed on this aspect of their lives, many female participants felt that the courts and other aspects of the system gave no credit to it. Carina commented on this with regard to the Cafcass assessment of her:
"[The Cafcass Officer] didn't really go into how [refusal of permission to relocate] would affect me at all [when we met] ... but in court she said, 'of course it would be devastating, but she's very capable and able to make a good life here'. Well, I don't see how someone can make that judgement about me without taking the time to talk to me about it." (Carina - unsuccessful mother).

This view was reinforced in those cases where - in contrast to Derek's case, noted earlier the mother was the only woman in the room when the decision was being taken. Both Eileen and Emily made specific reference to the fact that, in their cases, they were the only women in the court room. Despite winning her case, Emily felt that the whole system was like "an old boys ' club"; as she explained, "you've got a whole group of men - and you have to remember, I'm the only woman in the room - who all think Richard is 'a lovely chap'."

As well as female interviewees perceiving their status as mothers to be negated by the courts, they also saw their choices as regards their relationship and employment status as mothers become the source of direct moral judgment by legal professionals, judges and ex-partners. Much of the moral judgement used to condemn women revolved around their engagement with paid work whilst being a mother.

One case in particular illustrates this issue well. Gloria was the principle wage earner in her relationship, her ex-partner had been made redundant after they separated and she was carrying the financial responsibility for housing costs and the children's financial needs. Her grounds for wanting to relocate to the US were to do with a job promotion in the company she had been with for thirteen years, and which she not only felt some obligation to take, but also presented financial and emotional benefits for her children and her role as mother and 
breadwinner. Remaining in her current post in the UK would mean that the company would expect her to make frequent and lengthy trips abroad, whereas the US post would afford her greater flexibility, time off for her children and no travel away from home. Presenting her case in court, the interviewee described how her professional success and decision-making in relation to work was held against her and viewed as self-seeking:

"The professional thing got turned against me. So my ex's barrister was a Silk and won 'Family blah, blah of the year' - obviously very good - basically put me in a corner: 'here's a career woman, and doesn't she make a lot of money, and isn't she upwardly mobile, and isn't she just doing this to further her own interests and not the children's?"' (Gloria - unsuccessful mother).

The interviewee repeatedly defends her capacity as a mother throughout the interview to make clear that her professional achievement and decision-making did not jeopardize her devotion as a mother: 'I've always put them first [...] even my ex recognized that I'm an excellent mum.' The sexism which provoked the interviewee's need to defend herself against accusations of self-interest due to her professional success are startling in this case. When the interviewee won her case, such sexist perceptions about combining motherhood with career progression actually featured in the judge's report:

"And even in the final judgement, the judge wrote in the statement, 'she's obviously a successful woman who's used to getting her own way." (Gloria - unsuccessful mother).

In contrast to this case, women could also be judged as selfishly motivated and misguided if their life choices involved not being in paid employment as single mothers or when in new partnerships. One male interviewee criticized his ex-partner for entering into a new relationship in which the new partner was the only breadwinner, contrary to their previous partnership where he and his ex had both worked. He asserts that his ex-partner's decision to pursue relocation was based on some form of slovenly dependence, captured in the derogatory phrase, 'kept woman':

"She decided that she wanted to go and live the life of a kept woman over in Amsterdam and he was funding it." (Phil - unsuccessful father)

In another example, a male interviewee condemns his ex partner's request for higher levels of child maintenance after separation, claiming that being a single mother affords a privileged lifestyle: "[she wants to] live the high life of a single mother" (Victor - unsuccessful father). These cases suggest that heavy moral judgments are levied at women in the courts over their relationship to paid work (or not) in combination with motherhood and their economic dependence (or not) on men as mothers, a theme which is not apparent in the testimonies of men in this study. Such a finding reflects how recent social changes since the 1970s which have seen a decline in women's domestic status as housewives and rise in their role as wage earners, as well as an increase in families headed by single mothers, has created cultural 
ambiguities and prejudices about women's fulfilment of their duties surrounding paid work and motherhood, which are borne out in the courts. At the same time the persistence of a historic view by judges and within the legal system that a father's involvement in family life is paramount to its social standing, even when men pose a risk to the safety of children and women, reveals an unambiguous view about the value and function of fatherhood in modern society (see generally Kaganas 2006, 2013; Smart 2006).

\section{Children's views and involvement}

Many of the children in our relocation cases were very young, and so their views, as such, were not part of the case. However, a number of mothers spoke about how they felt that their children were completely sidelined from the decision:

"[There was] no interest in what 80\% of Rupert's life is like. ... [During evidence] there was no interest whatsoever in Rupert's possible life in Portugal. There were no questions coming from anyone about that." (Marina unsuccessful mother).

"Nobody, not even Richard, has said to me, 'how is Eve?'. Nobody ever asked about her. And do you know what? They never even asked where she was [while I was at court]. The presumption was: the mother will have sorted it. I have a photograph of her with me - nobody ever asks about her." (Emily - successful mother).

It may be that experiences were different with older children (though Eileen similarly commented that her 9-year-old daughter Lou was "not taken into account"). Ian and Malcolm, whose children were both 11, put their success in resisting the relocation application largely down to their children's views:

"The Cafacss report came back ... and it was just perfect for us, perfect for Polly. ... [The Cafcass Officer] took on board everything Polly said." (Ian successful father).

"Leo strongly didn't want to go. Even though he wasn't old enough to make the decision, I said to him 'if you say you want to go, I'll let you go, not because I want to get rid of you, but you've got a say in terms of what happens'.... He was very strong in terms of what he wanted to happen. ... Really the thing that clinched the final verdict [in the Independent Social Worker's report, which led the case to settle] was what Leo wanted to happen." (Malcolm - successful father).

Conversely, in Joseph's case, his 8-year-old son was strongly opposed to moving but " $h$ is opinion counted for zero"; on the other hand, his 14-year-old daughter "was insistently neutral" about the decision and "didn't want that responsibility", but nonetheless the judge 
decided that, beneath that veneer of neutrality, she wanted to relocate, and used that as the decisive factor in the case.

Many parents commented that their children were, in Dan's words, "all too aware" of the relocation dispute. As Dan went on to say, "upsetting as it is for us, it's devastating for Jamie. ... He's too old for his age, I think, with everything that's gone on". Graham similarly thought that the process "has been damaging for Owen, and it's something he'll never, ever forget. ... Emotionally, it's going to have damaged him." Clearly there is a fine line to be walked, between allowing children to have some input into important decisions about their lives, and protecting them from that process which mothers and fathers equally found highly stressful.

\section{Case outcomes}

For the most part, case outcomes in the immediate term were as expected, but in two cases the mothers who were refused permission to take their children overseas decided to move anyway, and the children now live with their fathers on a full-time basis. While both were delighted at having kept their sons with them, they were shocked that the mothers had actually left; as Malcolm said, "I still struggle today to believe that Linda went without him. I still don't get that - it makes no sense to me". On the flip side, Alan decided that he would move to follow his children to Australia; he had lived there briefly before, but didn't much like it, and so felt "absolutely gutted" about the decision.

Most of the mothers who were refused permission to move stayed and arrangements carried on largely as before; they were not actively thinking about re-applying in the future. Elspeth spoke about being “in prison here until Poppy's 16-another 11 years", which echoed Allie's bleakly-stated conclusion that "for the next 12 years, I can't move without a court order or Tom's say-so". Gloria talked about how upset she was, but that she didn't have any time to stop and recover:

“When you say, 'if I don't get to move, it will be devastating' ... actually, it is devastating - and as the primary carer, you still have to get up in the morning and make breakfast, but I honestly don't even know how to make life work right now. What I need to do personally is run away for a while and lick my wounds, and I can't."

For the fathers who won their cases - apart from Malcolm and Graham, whose former partners had gone without their children - there were frequent comments that it was only a matter of time before there was a renewed application. John, who had already had to go through lengthy Hague Convention abduction proceedings to get his children back to the UK before the relocation case arose, was sure that it was only a matter of time. Ian similarly said that "within two years, this is going to rear its head again", while Derek thought it would be "sooner rather than later". 
In terms of contact, for most children who did not relocate things generally carried on much as before, usually with fairly flexible arrangements involving lots of time with both parents, though there were various examples of difficulties. Janis felt angry that her former partner had "pushed for as much access as possible to look like the perfect dad in front of the social worker, and now he's got it ... he can't handle it. ... He got to 'win the relocation', but he also got all this access that he doesn't want." On the flip side, Elliot's son Paul was refusing to have any contact. Elliot accepted that Paul had been in favour of the move, and felt that Paul was blaming him for stopping him getting what he wanted. The parents disagreed about what, if anything, should be done about the problem though.

For those children who had relocated, on the other hand, experiences of contact in the first weeks and months after the move were very varied. Some of the mothers, like Laura and Nita, had found that contact was going quite well, though Laura found the unstructured plan something of an irritation. However, other mothers reported difficulties:

"I have to sit down with Shani on the laptop because she constantly wants to close it or thump on the keyboard. ... When I was in the UK, Henrik ... said he shouldn't have to miss seeing his daughter for one day, but now we're here he hasn't even used the first opportunity to get out here." (Marlies - successful mother).

“He hasn't phoned, emailed or skyped. ... I've messaged him on skype, messaged him in emails, left messages on his cell phone, but they're returned-a void email address. ... I don't even know where he is. But what's been really nice is that we've been able to re-establish [contact with] the paternal grandparents we skype with them." (Cecile - successful mother).

Fathers had similarly mixed experiences. Both Joseph and Samuel were generally positive about how things were going. For Joseph, "it's working reasonably well. The arrangements for the children aren't as good as if they were here and I was close by, but it's definitely not like it's a catastrophe". On the other side, other fathers spoke at length about the difficulties they had faced:

"Once you are outside the court, it doesn't matter if the pre-requisites for the entire order are ... just being flat out ignored. ... The judge spent 2 hours telling Johanna off. ... She got lambasted for [going back on what she'd said about contact], but in the end, of course, the parent with the children can do what they like and the courts can't or won't do anything about it." (Jakobunsuccessful father).

"The first weekend they were supposed to come back [for contact], they didn't - at all. ... The solicitor said they'd never seen anyone break an order so quickly and have such disregard for it. They asked us what Cheryl had complied with, and it was nothing! ... Cheryl said, 'unless you're going to take 
me back to court, there's nothing you can do about it'." (Phil - unsuccessful father).

\section{CONCLUSIONS}

Parents in this study found it difficult to talk about their experiences of being involved in a relocation dispute. Many found it hard to re-live an experience that they had found so distressing, though in the end they often commented that it felt better to have talked about things with someone independent of the process. Whether they were successful in getting what they wanted or not, parents uniformly described a highly stressful process which exacerbated existing difficulties and which often led to a significant deterioration in a previously amicable post-separation parenting relationship.

In many ways, these findings support those of earlier studies, particularly in relation to the difficulty of the process as well as the fundamental importance of the relocation decision to both parents. While mothers often observed that they thought that the family justice system in general unduly occupied with the value of fathers' rights, they did not relate that to the authorities on relocation specifically. On the other hand, they reported significantly gendered responses in terms of their life choices regarding their attachment to paid work as mothers and their relationship status following separation. It is also interesting to note that as well as reporting an overemphasis on the value of fathers' rights, the women in this study expressed the view that their work and knowledge as mothers was not credited by the courts. There is a suggestion that the specific worth of a mother has been obscured by the gender neutral term 'primary carer.'

By contrast, it is interesting, and perhaps concerning, that our male participants not only considered there to be significant bias in the family court system in favour of mothers, but identified that bias as operating in relation to Payne $v$ Payne in the relocation context in particular, even after $K v K$. It remains to be seen whether the change instigated by $\operatorname{Re} F$ will remove Payne from consideration or not, but it is notable that despite the criticisms levelled at it by Ryder LJ, Payne is not overruled by Re F. Depending on how judges interpret the effect of $\operatorname{Re} F$, it ma be that those who seek to depart from Payne entirely can find support from the views of fathers in this research since, whether it is a source of bias or not, the perception of Payne amongst fathers in this study was strongly negative.

Overall, even being interviewed weeks after their cases concluded, participants gave the impression of being exhausted and saddened by their experiences. The parents who got what they wanted were sad that it had taken so much effort to get there, and were often sad that a previously amicable relationship with the other parent had been strained (at the least) by the process. Marlies called it "bittersweet", while Emily said that "it didn't feel like a victory at all-it's an awful, awful situation". For those parents who had not got what they wanted, on the other hand, the distress and devastation of their situation was often very raw, even several months after the events. Recent reported cases have started criticising the use of the word 'devastation', but for both unsuccessful mothers and unsuccessful fathers in this study, that 
was the most frequently used word to describe how they felt and it fitted their overall accounts of the process.

\section{ACKNOWLEDGEMENTS}

We are very grateful to the 34 parents who gave up their time to talk to us about their experiences, and to the lawyers who helped us to get in touch with parents. This project was funded by a grant from the Nuffield Foundation, a charitable organisation with the aim of advancing social well-being. While the Foundation has supported our work, the views expressed are ours and are not necessarily shared by the Foundation.

\section{REFERENCES}

Devereux, E and George, R. (2014). 'When will the Supreme Court put us out of our Payne?'. Family Law, 44: 1586.

Devereux, E and George, R (2015). “"Alas poor Payne, I knew...”: An interpretation of the Court of Appeal's decision in Re F (International Relocation Cases)'. Family Law, 45: 1232.

Freeman, M. (2009). Relocation: the reunite research. London: Reunite.

Geekie, C. (2008). 'Relocation and shared residence: one route or two?' Family Law, 38: 1121.

George, R. (2014). Relocation disputes: law and practice in England and New Zealand. Oxford: Hart Publishing.

George, R. (2015). 'How do judges decide international relocation cases?'. Child and Family Law Quarterly, 27: forthcoming.

Harding, M and Newnham, A. (2015). How do county courts share the care of children between parents?. University of Reading and University of Warwick.

Hayes, M. (2006). 'Relocation cases: is the court of appeal applying the correct principles?' Child and Family Law Quarterly, 18: 351.

Hunt, J and MacLeod, A. (2008). Outcomes of applications to court for contact orders after parental separation or divorce. London: Ministry of Justice.

Kaganas, F. (2006). 'Domestic violence, men's groups and the equivalence argument'. In Diduck, A and O'Donovan, K, Feminist perspectives on family law. Abingdon: Routledge Cavendish.

Kaganas, F. (2013). 'A presumption that "involvement" of both parents is best: deciphering law's messages'. Child and Family Law Quarterly, 25: 270.

Parkinson, P and Cashmore, J. (2013). When mothers stay: adjusting to loss after relocation disputes. Family Law Quarterly, 47: 65.

Parkinson, P and Cashmore, J. (2015). 'Reforming relocation law: an evidence-based approach'. Family Court Review, 53: 23. 
Parkinson, P, Cashmore, J and Single, J. (2011). Mothers wishing to relocate with children: actual and perceived reasons. Canadian Journal of Family Law, 27: 11.

Rhoades, H. (2002). 'The "no contact mother": reconstructions of motherhood in the era of the "new father". International Journal of Law, Policy and the Family, 16: 71

Smart, C. (2006). 'The ethic of justice strikes back: changing narratives of fatherhood'. In Diduck, A and O'Donovan, K, Feminist perspectives on family law. Abingdon: Routledge Cavendish.

Taylor, N, Gollop, M and Henaghan, M. (2010). Relocation following parental separation: the welfare and best interests of children. University of Otago. 